\title{
ПІДВИЩЕННЯ НАДІЙНОСТІ ТА ЯКОСТІ ПРОДУКЦІї ЗАЛІЗНИЧНОГО ТРАНСПОРТУ
}

Канд. техн. наук А.О. Ніколаєнко, О.І. Солоділова

ПОВЫШЕНИЕ НАДЕЖНОСТИ И КАЧЕСТВА ПРОДУКЦИИ
ЖЕЛЕЗНОДОРОЖНОГО ТРАНСПОРТА

Канд. техн. наук А.А. Николаенко, О.И Солодилова

INCREASE OF RELIABILITY AND QUALITY OF PRODUCTS OF RAILWAY TRANSPORT

Cand. of techn. sciences A.A. Nikolaenko, O.I. Solodilova

Розглянуто методологію FMEA (Failure Modes and Effects Analysis - аналіз причин $i$ наслідків відмов), щэо подана в новому міжнародному стандарті залізничної промисловості IRIS.

Проведено FMEА-аналіз, побудована карта FMEA-аналізу колісних пар вагонів, а також визначені потенціальні параметри дефектності даних об'єктів.

Зроблено висновок, щчо систематичне застосування методології FMEA дасть змогу підвищитт якість продукиії та послуг на залізничному транспорті та окупиться завдяки: зниженню ймовірності повторних або нових відхилень за рахунок иілеспрямованого аналізу всіх критичних невідповідностей об'єкта; статистичному обліку ряду проблем, щзо дасть змогу уникнути помилок або повторних робіт.

Ключові слова: вагон, технічне обслуговування, ризик, статистичні методи контролю, якість, безпека, надійність.

Рассмотрена методология FMEA (Failure Modes and Effects Analysis - анализ причин и следствий отказов), что представлена в новом международном стандарте железнодорожной промышленности IRIS.

Проведен FMЕА-анализ, построена карта FMЕА-анализа колесных пар вагона, а также определены потенциальные параметры дефектности данных объектов.

Сделан вывод, что систематическое применение методологии FMЕА позволит повысить качество продукиии и услуг на железнодорожном транспорте и окупится благодаря: снижению вероятности повторных или новых отклонений за счет 
целенаправленного анализа всех критических несоответствий объекта; статистическому учету ряда проблем, который позволит избежать ошибок или повторных работ.

Ключевые слова: вагон, техническое обслуживание, риск, статистические методы контроля, качество, безопасность, надежность.

In the article considered methodology FMEA (Failure Modes and Effects Analysis - an analysis of the reasons and effect refusal) that is presented in new international standard of railway industry IRIS.

Organized FMEA-analysis, is built card FMEA-analysis wheel pair of the coach, as well as are determined potential parameters defect given object.

It Is Made conclusion that systematic using to methodologies FMEA will allow to raise the quality to product and services on rail-freight traffics and is dipped due to: reduction to probability repeated or new deflections to account of the goal-directed analysis all critical discrepancy object; the statistical account of the row of the problems, which will allow to avoid the mistake or repeated work.

Keywords: car, maintenance, risk, statistical control methods, quality, safety and reliability.

Постановка проблеми. Відсутність сформованої ринкової інфраструктури та необхідних знань, недостатній досвід роботи в сучасній економіці ускладнюють умови реформування залізниць. У зв'язку зі специфікою роботи залізничного транспорту поняття «ризику» та «невизначеності» повинні всебічно вивчатись для недопущення можливості їх виникнення. Із цією метою продовжують впроваджувати на залізничному транспорті України міжнародні стандарти якості.

Актуальність.

адміністрація залізничного транспорту України (Укрзалізниця) розглядає можливість впровадження в Україні Міжнародного стандарту IRIS - International Railway Industry Standard [1]. Стандарт задовольняє сучасні вимоги якості технічного обслуговування та ремонту продукції залізничної промисловості.

Мета статті. Провести аналіз транспортних подій та визначити вплив на них людського фактора. Застосувати методологію FMEA (Failure Modes and Effects Analysis - аналіз причин і наслідків відмов) [2], що наведена в новому міжнародному стандарті IRIS, 3 метою підвищення надійності і якості продукції залізничного транспорту.

Основна частина. У 2012 році допущено 9 транспортних подій -8 інцидентів, 3 них 1 серйозний та 1 порушення проти 20 (11 інцидентів та 9 порушень у 2011 році) - табл. 1.

Таблиця 1

Аналіз транспортних подій за 2012 рік

\begin{tabular}{|c|c|c|c|c|c|c|c|c|}
\hline \multirow{3}{*}{ Залізниця } & \multicolumn{4}{|c|}{ Інцидент } & \multirow{2}{*}{\multicolumn{2}{|c|}{ Порушення }} & \multirow{2}{*}{\multicolumn{2}{|c|}{$\begin{array}{c}\text { Інциденти та } \\
\text { порушення }\end{array}$}} \\
\hline & \multicolumn{2}{|c|}{ всього } & \multicolumn{2}{|c|}{ У т. ч. серйозні } & & & & \\
\hline & 2012 & 2011 & 2012 & 2011 & 2012 & 2011 & 2012 & 2011 \\
\hline Донецька & 1 & 1 & 0 & 0 & 0 & 2 & 1 & 3 \\
\hline Львівська & 1 & 1 & 0 & 0 & 1 & 2 & 2 & 3 \\
\hline Одеська & 0 & 5 & 0 & 0 & 0 & 0 & 0 & 5 \\
\hline Південна & 0 & 1 & 0 & 0 & 0 & 0 & 0 & 1 \\
\hline Півд.-Західна & 3 & 2 & 0 & 0 & 0 & 5 & 3 & 7 \\
\hline Придніпровська & 3 & 1 & 1 & 0 & 0 & 0 & 3 & 1 \\
\hline Разом & 8 & 11 & 1 & 0 & 1 & 9 & 9 & 20 \\
\hline
\end{tabular}


Рухомий склад та спеціальна техніка залізничного транспорту. Вагони

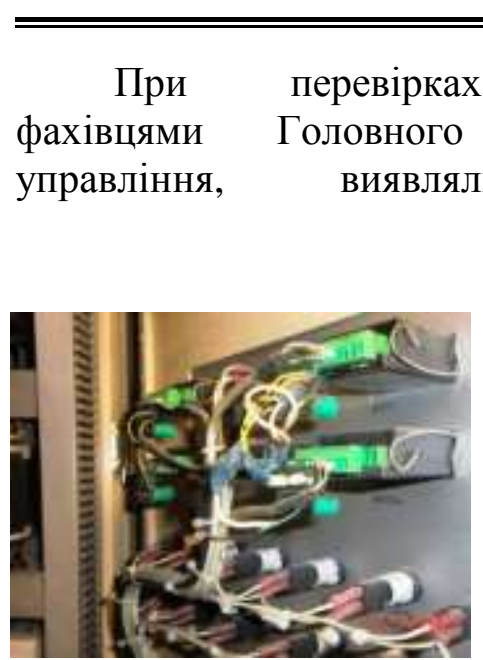

a

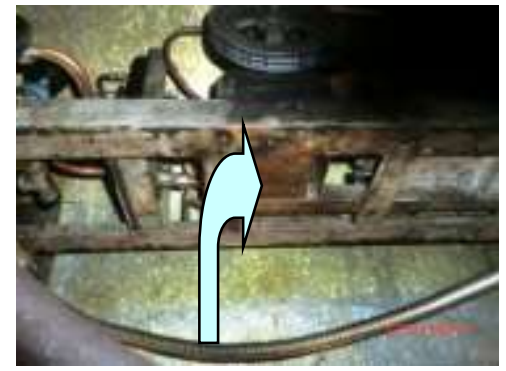

6

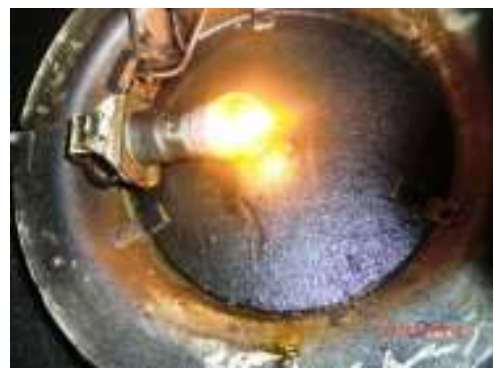

Рис. 1. Незадовільна якість ремонту пасажирських вагонів: a - холодні скрутки в електрощиті; б - протікання мастила з компресора вакуумного туалету на світильник у тамбурі

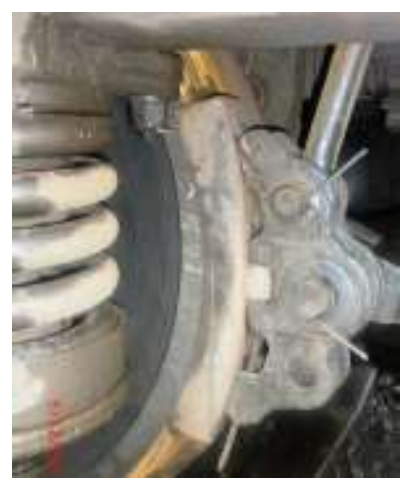

a

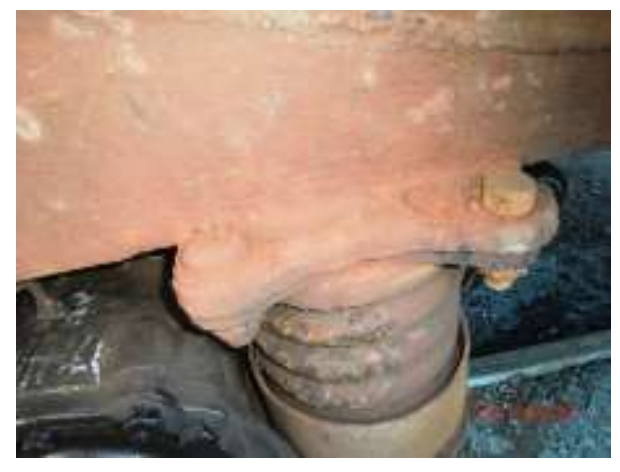

6

Рис. 2. Незадовільна якість ремонту пасажирських вагонів: a - експлуатація вагона з виходом колодки за обід тривалий час; б - незадовільна очистка рам візків від бруду
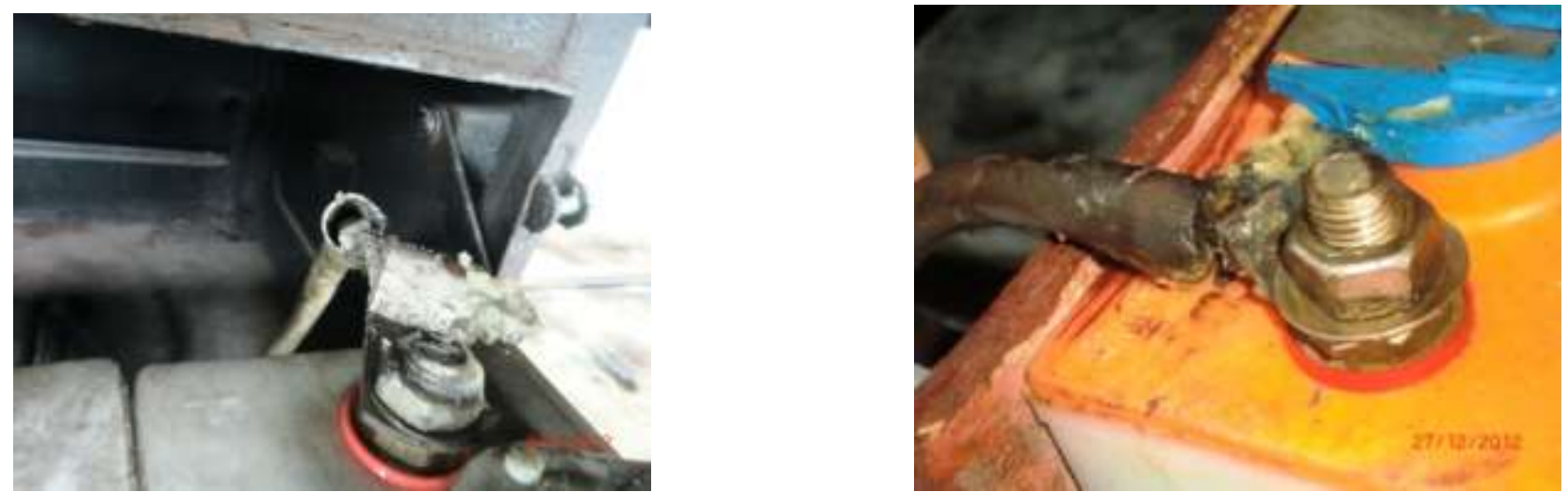

Рис. 3. На вагоні, випущеному з деповського ремонту, пошкоджено 1/3 жил кабелю 


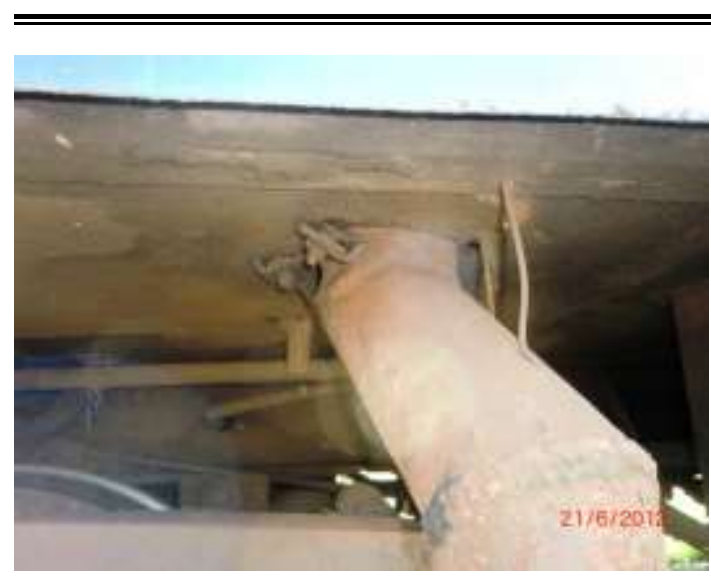

a

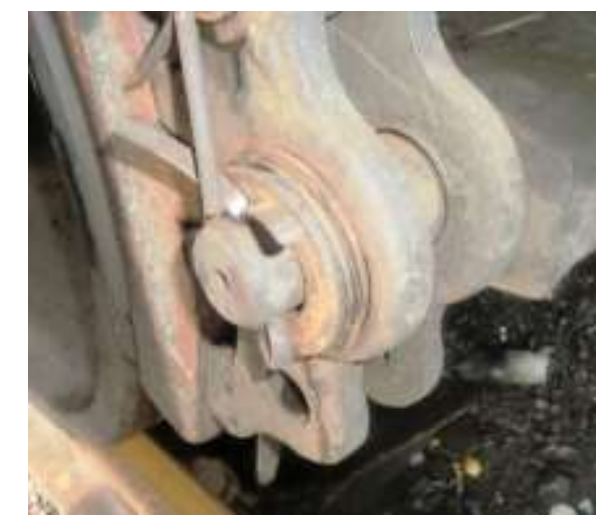

6

Рис. 4. Незадовільна якість ремонту пасажирських вагонів:

a - порушення кріплення фанових труб; б - встановлення п'яти шайб замість трьох

Як видно 3 рисунків, технологія ремонту порушується майже у всіх цехах та відділеннях i левову частку недоліків допущено через «людський фактор».

3 метою зниження ризиків, які виникають при технічному обслуговуванні та ремонті вагонів, доцільне впровадження міжнародного стандарту IRIS. Для керування ризиками у даному стандарті застосовується методологія FMEA.

FMEА-аналіз включає два основних етапи, поданих на рис. 5.

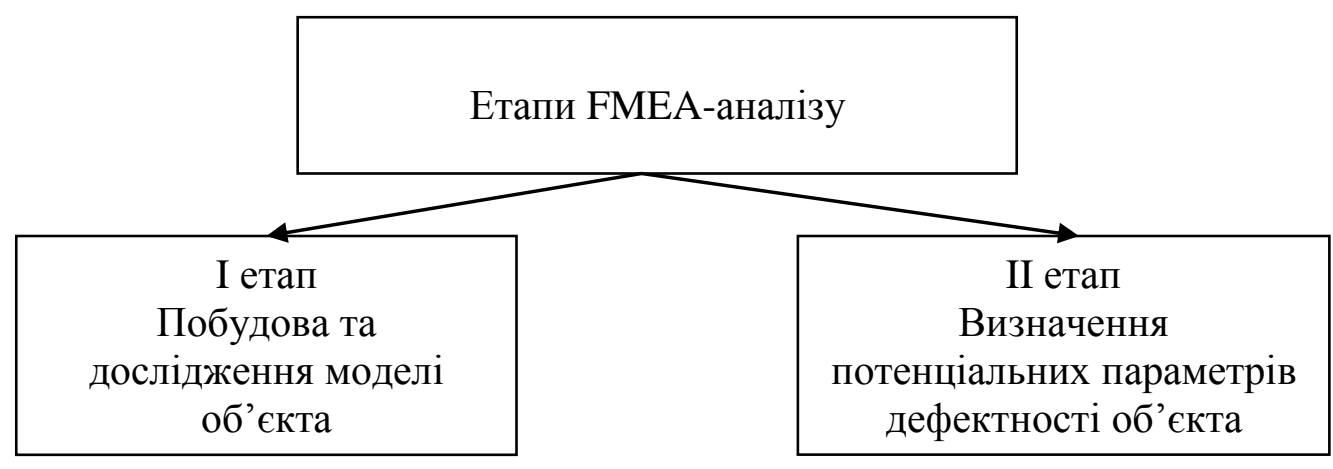

Рис. 5. Схема етапів проведення FMEA-аналізу

I етап включає в себе побудову компонентної, структурної, функціональної й потокової моделей об'єкта аналізу. Якщо FMEA-аналіз проводиться разом із функціонально-вартісним аналізом (ФВА), то використовуються раніше побудовані моделі. Далі проводиться дослідження моделей.

На II етапі визначаються: потенційні дефекти для кожного 3 елементів моделі об'єкта; потенційні причини дефектів; потенційні наслідки дефектів для споживачів, оскільки кожний $з$ розглянутих дефектів може викликати ланцюжок відмов в об'єкті; можливості контролю появи дефектів; параметр Е ваги наслідків для споживача; параметр А частоти виникнення дефекту; параметр В імовірності виявлення дефекту; параметр PRZ ризику споживача.

$\mathrm{Y}$ роботі [5] проведено дослідження причин виходу з ладу колісних пар вагонів. Виконано I та частково II етапи FMEAаналізу, а саме: на основі статистичних даних побудована діаграма Ісікави та 
експертним шляхом виявлені першопричини виходу з ладу колісних пар.

Аналіз статистичних даних за 20112012 pp. дав змогу визначити об'ємний показник якості утримання колісних пар в експлуатації (табл. 2).
Розподіл відмов наведено у табл. 3.

Побудуємо карту FMEA-аналізу для колісних пар № 436980 та №180971, які вилучені 3 експлуатації, та подамо ऑï у табл. 4.

Таблиця 2

Об'ємний показник якості утримання колісних пар в експлуатації

\begin{tabular}{|c|c|c|c|c|c|c|}
\hline \multirow[t]{2}{*}{ Залізниця } & \multicolumn{2}{|c|}{$\begin{array}{c}\text { Кількість вагонів, } \\
\text { відправлених в рейс }\end{array}$} & \multicolumn{2}{|c|}{$\begin{array}{c}\text { Замінено } \\
\text { колісних пар }\end{array}$} & \multicolumn{2}{|c|}{$\begin{array}{l}\text { Коефіцієнт } \\
\text { якості }\end{array}$} \\
\hline & 2012 & 2011 & 2012 & 2011 & 2012 & 2011 \\
\hline Донецька & 83490 & 84935 & 827 & 801 & 0,99 & 0,94 \\
\hline Одеська & 71367 & 92721 & 165 & 193 & $\mathbf{0 , 2 3}$ & 0,21 \\
\hline Південна & 98719 & 128598 & 217 & 370 & 0,22 & 0,29 \\
\hline Півд.-Західна & 119637 & 129578 & 870 & 893 & $\mathbf{0 , 7 3}$ & 0,69 \\
\hline Придніпровська & 122296 & 145943 & 635 & 795 & 0,52 & 0,54 \\
\hline Разом & 599105 & 688200 & 3354 & 3982 & 55,98 & 57,86 \\
\hline Донецьк & 33187 & 34443 & 347 & 336 & 1,05 & 0,98 \\
\hline Маріуполь & 16373 & 20446 & 135 & 204 & 0,82 & 1,00 \\
\hline Луганськ & 33930 & 30046 & 345 & 261 & $\mathbf{1 , 0 2}$ & 0,87 \\
\hline Львів & 40772 & 45122 & 221 & 327 & 0,54 & 0,72 \\
\hline Ковель & 20369 & 19237 & 162 & 291 & 0,80 & 1,51 \\
\hline Одеса & 45522 & 55504 & 151 & 156 & $\mathbf{0 , 3 3}$ & 0,28 \\
\hline Миколаїв & 15430 & 20586 & 11 & 24 & 0,07 & 0,12 \\
\hline Шевченко & 10415 & 16631 & 3 & 13 & 0,03 & 0,08 \\
\hline ВЧ Харків & 66891 & 86661 & 104 & 215 & 0,16 & 0,25 \\
\hline Суми & 11436 & 12663 & 42 & 63 & 0,37 & 0,50 \\
\hline Полтава & 20392 & 29274 & 71 & 92 & $\mathbf{0 , 3 5}$ & 0,31 \\
\hline Хмельницький & 10711 & 15364 & 119 & 103 & 1,11 & 0,67 \\
\hline Жмеринка & 15716 & 16732 & 23 & 55 & 0,15 & 0,33 \\
\hline Дніпропетровськ & 38796 & 43356 & 262 & 305 & 0,68 & 0,70 \\
\hline Запоріжжя & 29800 & 29295 & 104 & 127 & 0,35 & 0,43 \\
\hline
\end{tabular}


Таблиця 3

Розподіл відмов колісних пар в експлуатації

\begin{tabular}{|c|c|c|c|c|c|c|c|c|c|c|c|c|c|c|}
\hline \multirow[b]{2}{*}{ Несправність } & \multicolumn{2}{|c|}{ Донецька } & \multicolumn{2}{|c|}{ Львівська } & \multicolumn{2}{|c|}{ Одеська } & \multicolumn{2}{|c|}{ Південна } & \multicolumn{4}{|c|}{ Півд-Зах Придніпр. } & \multicolumn{2}{|c|}{ Разом } \\
\hline & 12 & 11 & 12 & 11 & 12 & 11 & 12 & 11 & 12 & 11 & 12 & 11 & 12 & 11 \\
\hline Повзун & 22 & 10 & 0 & 1 & 0 & 3 & 37 & 56 & 24 & 39 & 9 & 15 & 92 & 124 \\
\hline Прокат & 100 & 78 & 55 & 61 & 23 & 24 & 35 & 50 & 27 & 15 & 2 & 6 & 242 & 234 \\
\hline $\begin{array}{l}\text { Нерівномірний } \\
\text { прокат }\end{array}$ & 1 & 0 & 0 & 0 & 0 & 0 & 4 & 8 & 0 & 4 & 1 & 0 & 6 & 12 \\
\hline Вищербина & 166 & 128 & 18 & 36 & 51 & 58 & 68 & 97 & 129 & 72 & 4 & 9 & 436 & 400 \\
\hline Наварка & 1 & 1 & 0 & 0 & 0 & 0 & 0 & 11 & 20 & 3 & 11 & 30 & 32 & 45 \\
\hline $\begin{array}{l}\text { Кільцевий } \\
\text { виробіток }\end{array}$ & 10 & 23 & 29 & 23 & 0 & 2 & 0 & 1 & 14 & 8 & 52 & 54 & 105 & 111 \\
\hline Термотріщини & 13 & 16 & 98 & 99 & 0 & 0 & 0 & 0 & 256 & 218 & 346 & 356 & 713 & 689 \\
\hline $\begin{array}{l}\text { Розшарування } \\
\text { металу }\end{array}$ & 0 & 0 & 22 & 22 & 0 & 0 & 0 & 0 & 0 & 0 & 0 & 0 & 22 & 22 \\
\hline $\begin{array}{l}\text { Гострокінцевий } \\
\text { накат гребеня }\end{array}$ & 3 & 7 & 0 & 0 & 3 & 6 & 12 & 30 & 267 & 409 & 83 & 148 & 368 & 600 \\
\hline Тонкий гребінь & 148 & 151 & 62 & 62 & 35 & 38 & 2 & 2 & 10 & 0 & 32 & 21 & 289 & 274 \\
\hline $\begin{array}{l}\text { Різниця товщин } \\
\text { гребенів }\end{array}$ & 141 & 125 & 150 & 136 & 45 & 55 & 49 & 91 & 102 & 102 & 56 & 99 & 543 & 608 \\
\hline $\begin{array}{l}\text { Розширення } \\
\text { ободу }\end{array}$ & 49 & 95 & 1 & 3 & 6 & 7 & 4 & 21 & 13 & 12 & 21 & 31 & 94 & 169 \\
\hline Тонкий обід & 1 & 1 & 13 & 0 & 0 & 0 & 6 & 2 & 0 & 0 & 0 & 0 & 20 & 3 \\
\hline $\begin{array}{l}\text { Круговий } \\
\text { наплив металу }\end{array}$ & 7 & 4 & 0 & 0 & 0 & 0 & 0 & 1 & 4 & 7 & 15 & 22 & 26 & 34 \\
\hline $\begin{array}{l}\text { Викид мастила } \\
\text { через лабіринт } \\
\end{array}$ & 0 & 1 & 0 & 0 & 0 & 0 & 0 & 0 & 0 & 0 & 1 & 0 & 1 & 1 \\
\hline $\begin{array}{l}\text { Обводнення } \\
\text { мастила }\end{array}$ & 1 & 2 & 0 & 0 & 0 & 0 & 0 & 0 & 0 & 0 & 1 & 0 & 2 & 2 \\
\hline $\begin{array}{l}\text { Послаблення } \\
\text { торцевого } \\
\text { кріплення }\end{array}$ & 1 & 8 & 0 & 0 & 0 & 0 & 0 & 0 & 0 & 0 & 0 & 1 & 1 & 9 \\
\hline Перекіс букси & 0 & 0 & 0 & 0 & 0 & 0 & 0 & 0 & 0 & 0 & 1 & 2 & 1 & 2 \\
\hline $\begin{array}{l}\text { Вертикальний } \\
\text { підріз гребеня }\end{array}$ & 0 & 0 & 4 & 0 & 0 & 0 & 0 & 0 & 0 & 0 & 0 & 0 & 4 & 0 \\
\hline $\begin{array}{l}\text { Несправність } \\
\text { підшипників }\end{array}$ & 21 & 18 & 8 & 238 & 0 & 0 & 0 & 0 & 0 & 0 & 0 & 0 & 29 & 256 \\
\hline $\begin{array}{l}\text { Тріщина } \\
\text { корпусу букси }\end{array}$ & 0 & 2 & 0 & 0 & 0 & 0 & 0 & 0 & 0 & 0 & 0 & 0 & 0 & 2 \\
\hline $\begin{array}{l}\text { Несправність } \\
\text { редуктора }\end{array}$ & 28 & 29 & 4 & 23 & 2 & 0 & 0 & 0 & 4 & 4 & 0 & 0 & 38 & 56 \\
\hline $\begin{array}{l}\text { Різниця } \\
\text { діаметрів } \\
\text { колісної пари } \\
\end{array}$ & 114 & 102 & 176 & 226 & 0 & 0 & 0 & 0 & 0 & 0 & 0 & 1 & 290 & 329 \\
\hline ВСЬОГО & 827 & 801 & 640 & 930 & 165 & 193 & 217 & 370 & 870 & 893 & 635 & 795 & 3354 & $\begin{array}{c}398 \\
2\end{array}$ \\
\hline
\end{tabular}


Таблиця 4

Побудова карти FMEA-аналізу колісної пари вагона

\begin{tabular}{|c|c|c|c|c|}
\hline & $\begin{array}{c}\text { Потенційний } \\
\text { дефект }\end{array}$ & $\begin{array}{c}\text { Потенційні } \\
\text { причини }\end{array}$ & $\begin{array}{c}\text { Потенційні } \\
\text { наслідки }\end{array}$ & Вид контролю \\
\hline Вузол & $\mathrm{A}$ & $\mathrm{B}$ & $E$ & RPZ \\
\hline \multirow[t]{2}{*}{$\begin{array}{c}\text { Колісна } \\
\text { пара } \\
\text { № } 516980\end{array}$} & Термотріщина & $\begin{array}{l}\text { Порушення } \\
\text { технології } \\
\text { виготовлення }\end{array}$ & $\begin{array}{l}\text { Дефекти на } \\
\text { поверхні кочення, } \\
\text { вихід з ладу }\end{array}$ & $\begin{array}{l}\text { Руйнівний } \\
\text { контроль }\end{array}$ \\
\hline & 8 & 3 & 6 & 144 \\
\hline \multirow[t]{2}{*}{$\begin{array}{c}\text { Колісна } \\
\text { пара } \\
\text { №210973 }\end{array}$} & $\begin{array}{l}\text { Нерівномірний } \\
\text { прокат }\end{array}$ & $\begin{array}{l}\text { Порушення } \\
\text { технології } \\
\text { формування } \\
\text { колісних пар }\end{array}$ & $\begin{array}{l}\text { Передчасний вихід } \\
\text { з ладу }\end{array}$ & Діагностика \\
\hline & 2 & 4 & 5 & 40 \\
\hline
\end{tabular}

Виходячи 3 табл. 4 коригувальні заходи щодо результатів аналізу доцільно проводити в такій послідовності:

- виключити причину виникнення дефекту в результаті слідування технології виготовлення коліс для унеможливлення виникнення дефекту (зменшити параметр A),

- знизити вплив дефекту (зменшити параметр Е). Мається на увазі, що вихід 3 ладу колісної пари, що експлуатується, може привести до аварій та катастроф;

- полегшити й підвищити вірогідність виявлення дефекту (зменшити параметр В) за рахунок чіткого дотримання технологічного процесу виготовлення колеса.
Що стосується коригувальних дій, згідно 3 табл. 4, можна відзначити, що в першу чергу необхідно вжити заходів до усунення потенційних причин виникнення дефекту «термотріщина», з огляду на те, що величина параметру ризику споживача (RPZ) вище, ніж 125 балів [2].

Висновки.

Систематичне застосування методології FMEA дасть змогу підвищити якість продукції та послуг на залізничному транспорті та окупиться завдяки скороченню витрат засобів і часу на позапланові заміни виробів, статистичний облік ряду проблем дасть змогу уникнути помилок або повторних робіт.

\section{Список використаних джерел}

1. Dr. David Scrimshire. IRIS - Global business management system for the railway industry supply chain // Technical Paper. — December, 2006.

2. Анализ видов и последствий потенциальных отказов. FMEA [Текст]: справ. Руководство / Крайслер корпорейшн, Дженерал Моторс корпорейшн; пер. с англ. Н. Новгород: АО «НИЦ КД»: СМЦ «Приоритет», 1997. - 67 с.

3. Дотянуться до стандарта [Текст] // Сириус. Транспортное обозрение. - 2007. № 11. - С. 46-50.

4. ISO 9001:2001. Quality management systems - Reguirements (Системи управління якістю - Вимоги) [Текст]. - К.: Держстандарт, 2008. 
Рухомий склад та спеціальна техніка залізничного транспорту. Вагони

5. Ніколаєнко, А.О. Удосконалення нормативної бази для вхідного контролю колісних пар вагонів [Текст]: дис. ... канд. техн. наук: 05.01.02: захищена 28.07.2008; затв. 13.11.2008 / А.О. Ніколаєнко. - Севастополь, 2008. - 151 с. - Бібліогр.: с. 68-115.

6. Аналіз стану безпеки руху в пасажирському господарстві за 2012-2013 pp. - К.: Укрзалізниця, 2012.

Рецензент д-р техн. наук, професор I.Е. Мартинов

Ніколаєнко Анна Олександрівна, канд. техн. наук, старш. викл. кафедри вагонів.

Солоділова Ольга Іванівна, слухач ІППК, гр. МЗ-В-Б-11.

Nikolaienko A.O., cand. of techn. sciences; Solodilova O.I. 